\title{
Impact of COVID-19 pandemic on logistics performance, economic growth and tourism industry of Thailand: an empirical forecasting using ARIMA
}

\author{
Laeeq Razzak Janjua', Fida Muhammad², Patthaphon Sukjai ${ }^{3}$, Abdul Rehman ${ }^{4}, Z^{2} a n g$ Yu $^{5}$
}

${ }^{1}$ Poznan University of Economics and Business, Poznan, Poland.

¿University of Karachi, Karachi, Pakistan.

${ }^{3}$ Kasetsart University, Kamphaend Saen, Thailand.

${ }^{4}$ Chang'an University, Department of Management Sciences, Xi'an, China.

${ }^{5}$ Chang'an University, School of Economics and Management, Xi'an, China.

How to cite: Janjua, L.R., Muhammad, F., Sukjai, P. et al. (2021), “Impact of COVID-19 pandemic on logistics performance, economic growth and tourism industry of Thailand: an empirical forecasting using ARIMA", Brazilian Journal of Operations \& Production Management, Vol. 18, No. 2, e2021999.

https://doi.org/10.14488/BJOPM.2021.001

\section{ABSTRACT}

Goal: The tourism sector always plays a vital role among other sectors, which contributes heavily to Thailand's GDP. Due to the recent Pandemic crises, the tourism industry worldwide faces a decline. The aim of writing this paper is to forecast, tourist inflow for Thailand for the next nine months by using ARIMA forecasting

Design / Methodology / Approach: In order to meet the study objective, we adopted the univariate time series forecasting of tourist arrival. The $A R(12)$ and $M A(12)$ process with $d(1)$ order to specify the appropriate model also applied for forecasting selection of international tourist arrivals, after diagnostic checking of series through correlogram Q-statistics and correlogram of residuals for adjusted ARIMA $(12,1,12)$ in which we found low residual against 70 lags.

Results: The evidence predicts that in the next nine months, Thailand will face significant negative zone arrival of international tourists due to the COVID-19 pandemic crises, which adversely affect Thailand's economy due to the shortfall of international tourist arrivals. However decline in tourist arrival will eventually decrease air pollution in Thailand, thus it positively impact on environmental quality.

Limitations of the investigation: In terms of limitation of this study, this forecasting is only valid for Thailand based on historical and current data.

Practical implications: We highly recommend government of Thailand for enchasing overall logistics performance and furthermore increase use to renewable energy and green performance in their tourism sector.

Originality / Value: This study provides tourism forecasting estimation for Thailand, which can help government to reshape their tourism policies due to Covid-19 pandemic crises. As this study is the first attempt to provide forecasting related with Covid-19 for tourism sector.

Keywords: Forecasting; Economic Growth; Covid-19; Tourism; Green Practice; Renewable Energy.

Financial support: This work partially supported by the Beijing Key Laboratory of Megaregions Sustainable Development Modelling, Capital University of Economics and Business (No. MCR2019QN09).

Conflict of interest: The authors have no conflict of interest to declare.

Corresponding author: zhangyu19@foxmail.com

Received: 12 June 2020

Approved: 22 Sept 2020.

Editor: Syed Abdul Rehman Khan. 


\section{INTRODUCTION}

Tourism is known to be one of the critical drivers of the economy and many impacts in many direct and indirect ways. Some of the essential benefits of tourism include the creation of jobs, rolling of money and spending in the community, diversification of the economy, infrastructure development, and social advantages like people of the land feel proud to be inhabitants of the area, entrepreneurship, and much more. When religion, faith, or spirituality is connected with tourism, the advantages and benefits increase significantly, and the prime factor is the assurance of tourists every year or very cycle (Crompton, 1970). Travel and tourism have a direct impact on the world economy. The travel and tourism industry globally contributes $9.8 \%$ of the world GDP that accounts for the US $\$ 7.6$ trillion. In the year 2014 , the total number of jobs in this segment was 277 million, and this means every 11 th job belonged to this sector, in 2014 alone 2.1 million direct posts was created, and 6.1 million indirect jobs were created due to the economic activity in this sector (Luton, 2010).

Furthermore, during 2019, 1.5 billion international arrivals were recorded in different regions of the world, and for 2020 there was a projection to increase it by $4 \%$ (World Tourism Organization, 2020). According to the World Tourism Organization (2020), three top rank countries are France, Spain, and the United States of America, and more specifically from the Asian region, China ranked 4rth and Thailand Ranked 9th from East Asian Region. In 2018, 38 million international tourist arrivals were recorded in Thailand. Beside leisure and pleasure, the massive contribution among the foreign tourist in Thailand was also due to Religious factors, thus religious tourism. According to the estimation of (Thailand Tourism Authority: 2019), $6 \%$ of Thailand's GDP based on the Tourism Sector. The land of Thailand enriches with old Buddhist temples and religious schools, thus famous as Buddhist Tourism hub. Religion, faith, and spirituality are some of the biggest reasons for traveling and religious or hope based tourism has a very high intrinsic and inherent motivation as well. People go basically for two purposes only. First, they would visit to explore a place for leisure or any symbolic or natural association of the situation and second for their experience, faith, conviction, and attitude. Religious tourism can fall into the second category of reason. What are the actual reasons that compel people to visit a revered place once or many times is not elaborately discovered in the literature? Tourists motivated through religious or faith-based motives differ from other pleasure-seeking tourists. Religious tourism can be illustrated as a journey undertaken by a devotee to a sacred site or a trip to perform some rituals. Religious tourism can also be delineated as visiting a place or venue for spiritual gains (Blackwell, 2007). As Drayman et al. (2018) in their work mention that, the tourism sector is the driver for disaster recovery. Furthermore, tourism also brings peace and stability in conflicted areas.

\subsection{COVID-19 The Contemporary world situation}

Covid-19 is not an issue of a single community or country, as it is declared as global Pandemic crises, which spread over more than 160 countries of the world. In the past, one of the significant crises hit the tourism sector especially was the Tsunami of 2004, which hit almost 15 countries of the Indian Ocean, and more than 200000 people lost their lives. It was a natural disaster, as (Prideaux et al., 2003) disasters are unpredictable catastrophic change; usually it happens all of a sudden and it usually can be responded after the event, furthermore response is possible either by contingency plans or by through reactive responses as well. Similarly, Neef and Grayman (2018) most pandemic crises like SARS or other regional crises such as EBOLA are characterized both by, natural hazard and human failure. Furthermore, they also argue that boundaries between natural and human made disasters or crises are fuzzy at best. However, the Covid-19 crises start spreading around the world from December 2019 , and hit every sector of the world, as most of the countries of the world are entirely lockdown situation. As Ali and Cobanoglu, (2020), predict their work that under the current circumstances of international travellers can be shrinking from 1.4 to 1 billion. Furthermore, they also reveal that approximately 50 million jobs could be lost. 
The aim of writing this paper is to forecast inbound tourists for the next nine months for Thailand. Besides the agriculture and industrial sector, one of the significant contributors to Thailand's economy is Tourism, which contribute 6\% in GDP and also creates massive number of direct and indirect jobs in tourism sector.

\section{LITERATURE REVIEW}

To empirically illustrate the relationship between tourism and economic growth, (Ongan and Demiroz, 2005) conducted an empirical study by using VECM and Johansen co-integration analysis, covering the period 1980 Q1 to 2004 Q2 for Turkey. They conclude that there is a long-run association exists between Economic growth and Tourism. Furthermore, they also indicate that there is bidirectional causality exists between economic growth and tourism. Similarly, in the case of panel data analysis, (Selimi et al., 2017) empirically investigate the impact of tourism on economic growth for six Balkan countries Albania, Bosnia and Herzegovina, Croatia, FYROM, Montenegro and Serbia covering the period 1998 to 2014. By using fixed effect and random effect models, they reveal that there is a positive and significant relationship that exists between tourism and economic growth. Thus tourism sector positively contributes to economic growth.

To explore the relationship between economic growth and tourism, (Chou, 2013) conducted a panel study for ten transition countries and concluded that tourism development accelerates economic growth in transaction countries. Furthermore, he also reveals that the growth hypothesis hold for Latvia, Slovakia, and Cyprus. Poland, and the Czech Republic, it is reverse. On the other hand, the feedback hypothesis holds for Estonia and Hungary. Similarly, in the case of India, (Dash et al., 2018) used ARDL estimation covering the period 1973 to 2013, and indicated that in the case of the short and long-run, tourist has a positive impact on economic growth. Therefore, their investigation found that the tourism lead growth hypothesis correct for India. Furthermore, Due to Hinduism and Buddhism, the Indian tourism sector is heavily based on religious tourism. In the case of Italy and Spain (Cortes-jimenez and Pulina, 2010) used the VECM and Granger causality test to investigate tourism lead economic growth hypothesis and found that it valid for Italy and Spain. In their research work, they used time spam covering the period 1950s to 1960s.

On the other hand, Chen and Chiou-wei, (2009) examined the causal relationship between tourism expansion and economic growth for Taiwan and Korea by employing the EGARCH-M model. Their investigation reveals that, in the case of Taiwan, they found Tourism led growth hypothesis right, and on the other hand, in the case of South Korea, their investigation indicates reciprocal causal relationship for South Korea. More specifically in case of Thailand, Wattanakuljarus and Coxhead (2008) investigated impact of inbound tourist on income distribution. Their research indicates that inbound tourism demand raises aggregate household income but on the other hand, its distribution is not satisfactory. Due to the fact in Thailand tourism sector is not labour intensive as majority of people engaged in Agriculture sector. Furthermore, Chancharat (2011) conducted explorative research and hypothesis by his explanation that, as Thailand is famous tourist country among the international tourist, therefore tourism sector can have an essential contribution in overall Thailand's economy. Moreover, in the case of Religious tourism, it also indicates a positive association with economic growth. As Pourtaheri et al. (2012) Conducted qualitative research, and conclude that religious tourists for pilgrims are strongly influenced in rural areas, such that have a substantial impact on the rural household. Similarly, to show the relationship between logistics and transportation with inbound tourism, Khan et al. (2019) empirically investigate that relationship for Thailand using ARDL estimation. They conclude that the logistic and transportation sector positively impact inbounds tourism.

\subsection{Major attributes of Thailand's tourism}

The Kingdom of Thailand is a country with a long history and history. Until today Thailand is participating in world ongoing history in terms of art, culture, tradition, and more especially 
as a hub for Buddhism. Among international tourists, it is always on the top due to artistic and cultural tourist destinations in the world. Especially as the land of Buddhism, the religious roots are so deep in their culture and traditions. Therefore the massive number of international tourists every year visits Thailand to see Grand Palace and the Temple of the Emerald Buddha (Wat Phra Kaew), According to the Tourism Authority of Thailand, during 2019, $(881,996)$ international tourists visited Grand place, and they paid 308.69 million baht as entry ticket fees.. Besides that, Phra Nakhon Si Ayutthaya is another famous destination for international tourists. According to the estimate of, tourism authority of Thailand from Jan 2018 to May 2018, approximately 14.16 million foreign tourists arrived in, of which 6.62 million of them were visiting religious sites and practicing religious activities.

Furthermore, according to the survey of (Department of Tourism) tourists from East Asia such as China, Taiwan, Hong Kong, Japan being paid over 15 million baht just for their living in renting properties. According to the estimate of the Religious division of Thailand, there are 41,310 temples exist in Thailand. Three hundred ten temples are under the supervision of the Royal family of Thailand, thus renovate and build by Buddhist Monks. Among 310 temples, 247 temples belong to Mahayana. After royal family supervision, 41,030 temples separated into 37,225 Mahayana, 3,769 Chinese temples, and 5828 belongs to other Buddhist communities. Department of Religious Affairs (2015) has, therefore, mentioned the benefits which can be derived from religious tourism in multiple ways. Initially, it is the use of social capital that exists in society to benefit the people in the community making temples and religious places a living and potential tourist destination. Similarly, it also provides a system for managing tourist routes. Buddhist principles that are effectively Support the needs of the moral tourism of society. On the other hand, it integrates, cooperate, and promote government roles in private and public sectors to participate in continuing the creative development of tourism in the religious dimension. Temples and communities have systematic management of Buddhist tourism. Make Buddhist tourist attractions Known throughout the country and around the world. It is also allowing temples to play a role in tourism, which will have direct benefits to the tourists and indirect benefits for community service.

Similarly, Thailand provides freedom in religion. Thai people, therefore, choose different religions. Most of the population is Buddhist. There is no law in the Constitution of the Kingdom of Thailand, which indicates that, Buddhism as a national religion. According to the National Statistical Office, they are indicating that $94 \%$ of the Thai populations are Buddhists. Most of them are Theravada sects, and 5\% are Muslims, with 99\% of mosques in Thailand belongs to Sunni community, while Shi'a mosques are only $1 \%$. Christianity is about 400,000 people, representing 0.7 percent of the population throughout the country. There are both Catholic and Protestant. Approximately 70,000 Sikhs people living in Thailand. Most of them live in Bangkok and other major cities such as Chiang Mai, Nakhon Ratchasima, Pattaya, and Phuket. There are 19 Sikhs around the country. There are about 10,000 people belongs Hinduism. There are also religions and other religions, such as Taoist, Confucian, and Jewish, as well as nine hill tribe people, approximately 920,000 people of different religions (Religious Information Center, 2020). Furthermore, Thailand is famous for its beaches and also night light among international travelers. Similarly, the upper part of Thailand is consisting of tropical forest which is also famous among tourists from all around the world as well as hundreds of Tropical Island. Thailand is also famous for its medical tourism, in 20182.5 million tourist visit Thailand for medical purposes.

The objective of this study is to estimate the historical tourism demand and forecasting of T-demand through using Box-Jenkins time series approach, particularly the Autoregressive integrated Moving average (ARIMA). For this reason, we used enough large historical international tourists' arrival data in Thailand from January 1991 till March 2020 and forecasted till December 2002. We drive several ARIMA models and evaluated through some of statistical criteria such as Akaike information criterion (AIC), Schwarz Bayesian criterion (SBC), standard error and maximum likelihood. 


\section{METHODOLOGY}

To achieve our research goal, we applied the Autoregressive moving average method as it is a well famous modeling technique for predicting future values of any time series variable based on "past values." This model is also known as Box-Jenkins (1976) methodology. To satisfy our study objective, via forecasting tourism demand, this methodology is used under the consideration of the classical assumption of stationary AR process and Invariability for the MA process for modeling and choosing of selection for an appropriate model.

\subsection{Model specification:}

According to Box-Jenkins (1976) technique, the time series model of $Y_{t}$ is explained by the lagged values of $Y_{t}$ or $Y_{t-k}$ and a random stochastic error term $u_{t}$ which simply means that future value of any variable can be determined on the basis of historical values of $Y_{t}$ and no other repressors are involved in such reduced form equation. This type of modelling, also known as a theoretical model because it does not drive by any economic theory

For this reason, ARMA is composed of two different models AR, and MA as follows.

$Y_{t}=\gamma_{0}+\vartheta_{i} Y_{t-1}+\ldots \vartheta_{p} Y_{t-p}+U_{t}$

Where $Y_{t}$ is any time series, which is assumed to be linearly dependent, its own lags p-order, and $\gamma_{0}$ is constant term \& $U_{t}$ shows error term. Meanwhile $\mathrm{E}\left(U_{t} Y_{t-1,}, Y_{t-p}\right)=0$.

The generalized form of AR (pth) ordered can be rewrite as Equation 2.

$Y_{t}=\gamma_{0}+\sum_{i=1}^{P} \vartheta_{i} Y_{t-p}+U_{t}(2)$

Similar to AR model, the generalized form of MA (qth) ordered equation can be expressed as:

$Y_{t}=U_{t}+a_{i} U_{t}+\sum_{i=1}^{P} a_{i} U_{t-q}$

To observe the pattern of dependent variable $Y_{t}$, explained by current and lags values of current error term. The ARMA order $(p q)$ can be presented as characteristics of both AR and MR process on equation derived for $Y_{t}$, thus ARMA.

$Y_{t}=\gamma_{0}+\sum_{i=1}^{P} \vartheta_{i} Y_{t-p}+U_{t}+\mathrm{a}_{i} U_{t}+\sum_{i=1}^{P} \mathrm{a}_{i} U_{t-q}$

\subsection{ARIMA Model}

Economic variables that exhibit the movement with time often are not stationary, that they are integrated at different orders as the preceding variable under this study Tourism demand shows seasonal changes which might be non-stationary at request I (0). Thus performing ARMA cannot be suitable to forecast tourism demand with accuracy. Hence they may be integrated at I (d) by difference. An Autoregressive integrated moving average can be expressed as ARIMA ( $p d q)$. Where $p$ donates the number of AR, $d$ donates at which variable becomes stationary, and $q$ gives the number of MA process in an equation.

\subsection{The Box-Jenkins (BJ) (1976) Methodology}

The Box-Jenkins (1976) methodology consists of four steps or also famous as a four iterative step methodology for identifying an appropriate model for predicting the future value of tourism demand. That's the identification of order $(p d q)$, parameter estimation, diagnostic 
checking for estimated residuals either white-nose if yes, then forecasting. It can be possible after concerning the theoretical and empirical autocorrelation pattern to identify on or more possible models for tourism demand. It usually can be done through ACF (autocorrelation function) and PACF (partial autocorrelation function) for the given sample from Jan 1991 to March 2020 as a tool for determining the order $p$ and $q$ for ARIMA. These tools also proposed by Box-Jenkins (1976). So far, the primary concentration for step one (identification), we must produce a stationary time series which essentially required for the ARIMA model. If the series, let say $Y_{t}$ is not stationary, we can produce as $\Delta Y_{t}=Y_{t}-Y_{t-1}$ differencing series with previous lag of $Y_{t}$ to obtain constant mean and variance for to remove trend and stabilized the variance, before moving toward ARIMA model. That allows us to move on the second step to estimate parameters and helps us for model selection by reducing residuals. Before we move to forecast series, we must follow diagnostic tests for model competency. Furthermore, it is possible, if we make sure that error is contended by testing hypothesis through diagnostic statistics and plots of residuals. If the model is not satisfactory, we shall repeat the earlier steps again and again. The Box-Jenkins (B-J) model establishes a process approach to monitor and repeat till the accomplishment of a high degree satisfaction about the model that is having minimum errors. Thus, the B-J methodology is known as an iterative process. Therefore we can apply this model to forecast tourism demand using an extensive series of monthly data; meanwhile, it is approved by other researchers.

\section{RESULTS AND DISCUSSION}

In this study, we have forecasted the tourism demand using the large dataset of international tourist arrival in Thailand. Our research is based on B-J (1976) methodology, which consists of the four-step method of forecasting tourism demand as identification, estimation parameters, diagnostic checking, and forecasting. Figure 1 indicates the international tourist arrival trend in Thailand from January 1991 to March 2020 at Suvarnabhumi airport and Don Muang Airport. It can be seen that in March 2020, the tourist arrival is dropped significantly. The declined in tourist flow is never experienced in Thailand from its historical trend. The seasonal pattern can be seen in Figure 2. The highest average number of tourist arrival seen higher in March as compared to other months and declines gradually till December.

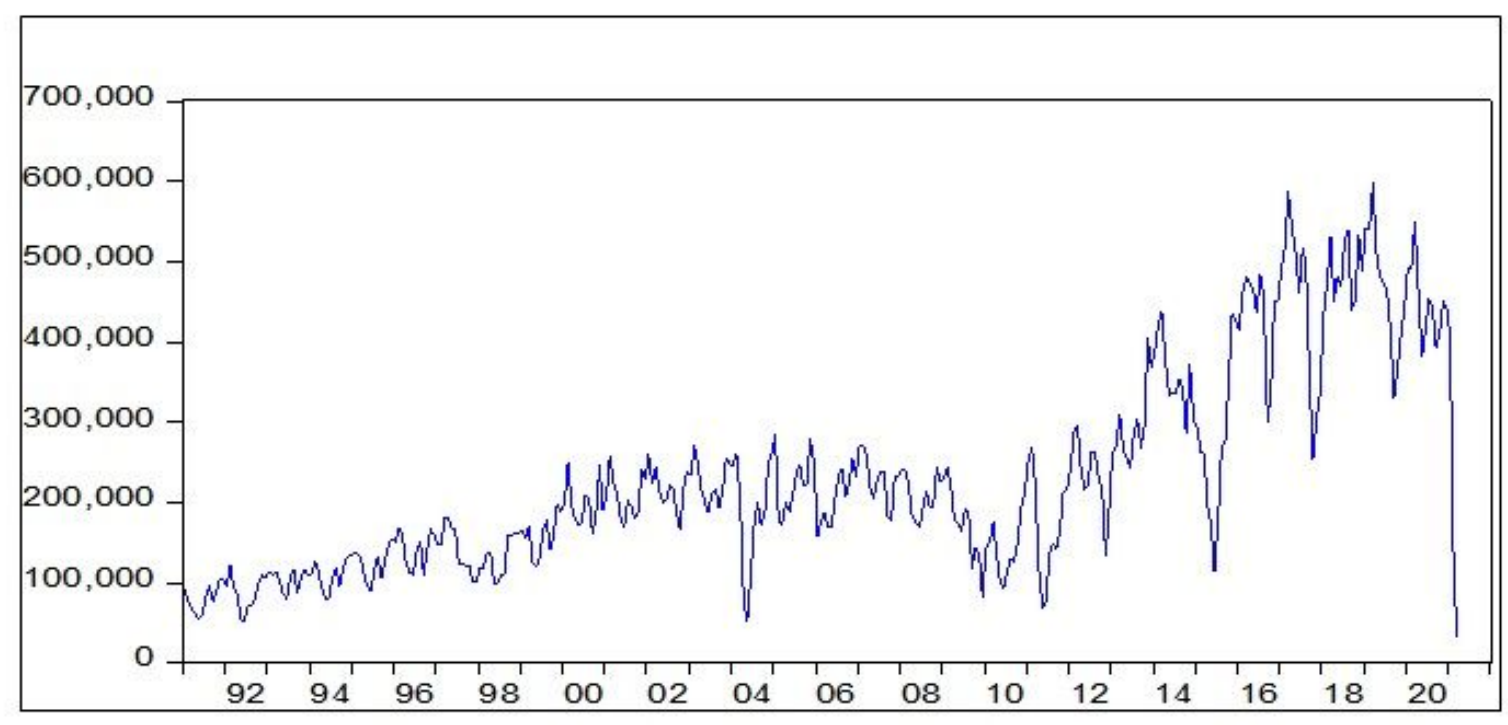

Figure 1. International Tourist Arrival Trend (Jan-1991 to March 2020). Source: Tourism Authority Thailand 


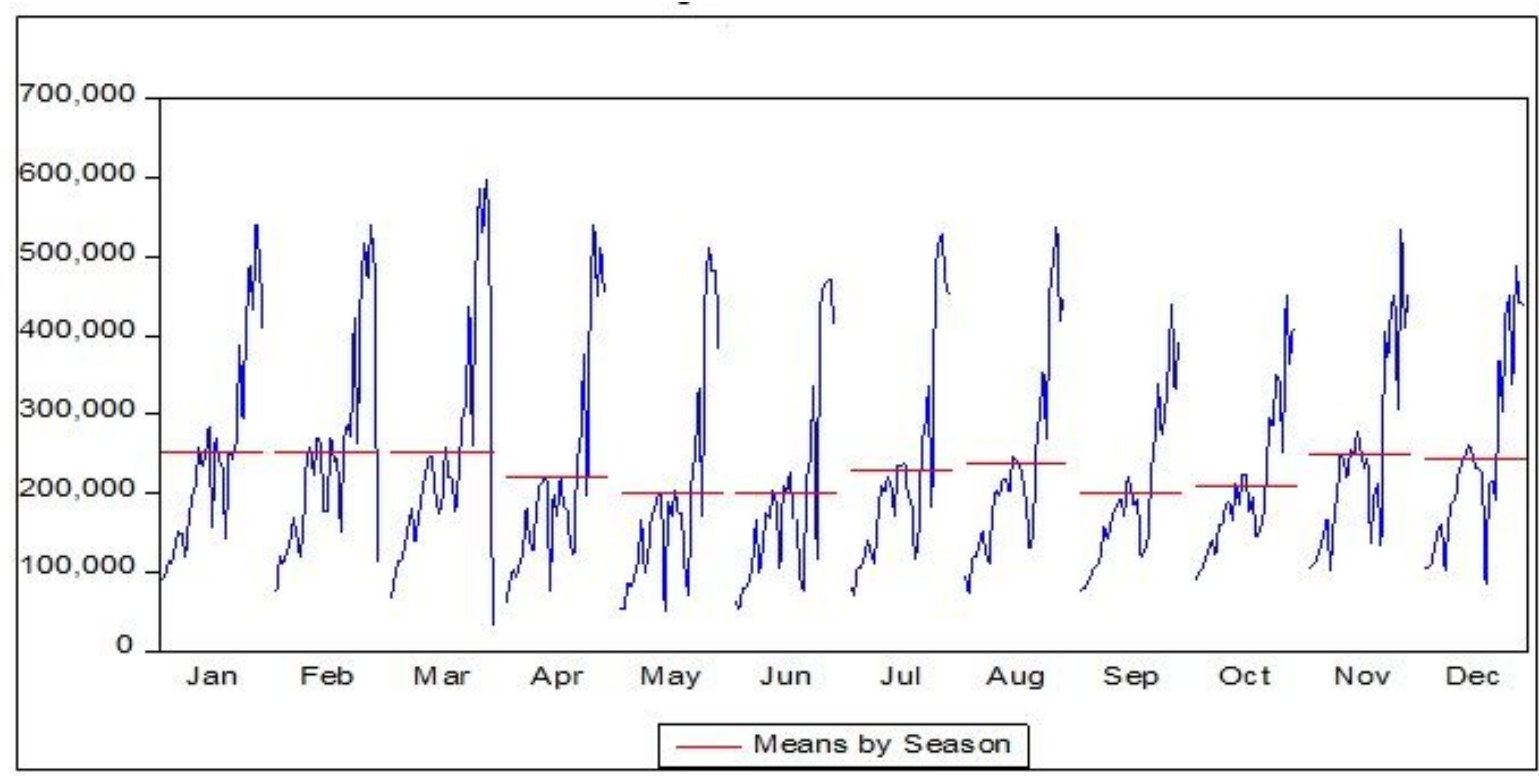

Figure 2. Seasonal Patterns of International Tourist Arrivals (Jan-1991 to March 2020). Source: Tourism Authority Thailand

\subsection{Model Identification:}

Step one consists of checking the stationary level of series. To follow step one, we make sure either series is stationary or not. If it is stationary, we will move to ARMA to choosing the possible order of pth AR and qth MA process. Otherwise, we will make data stationery by taking difference and ultimately ARIMA. As the trend in Figure 1 shows the non-stationary characteristics of the series. Hence choosing the difference of Tourist Arrival series as presented in Figure 3.

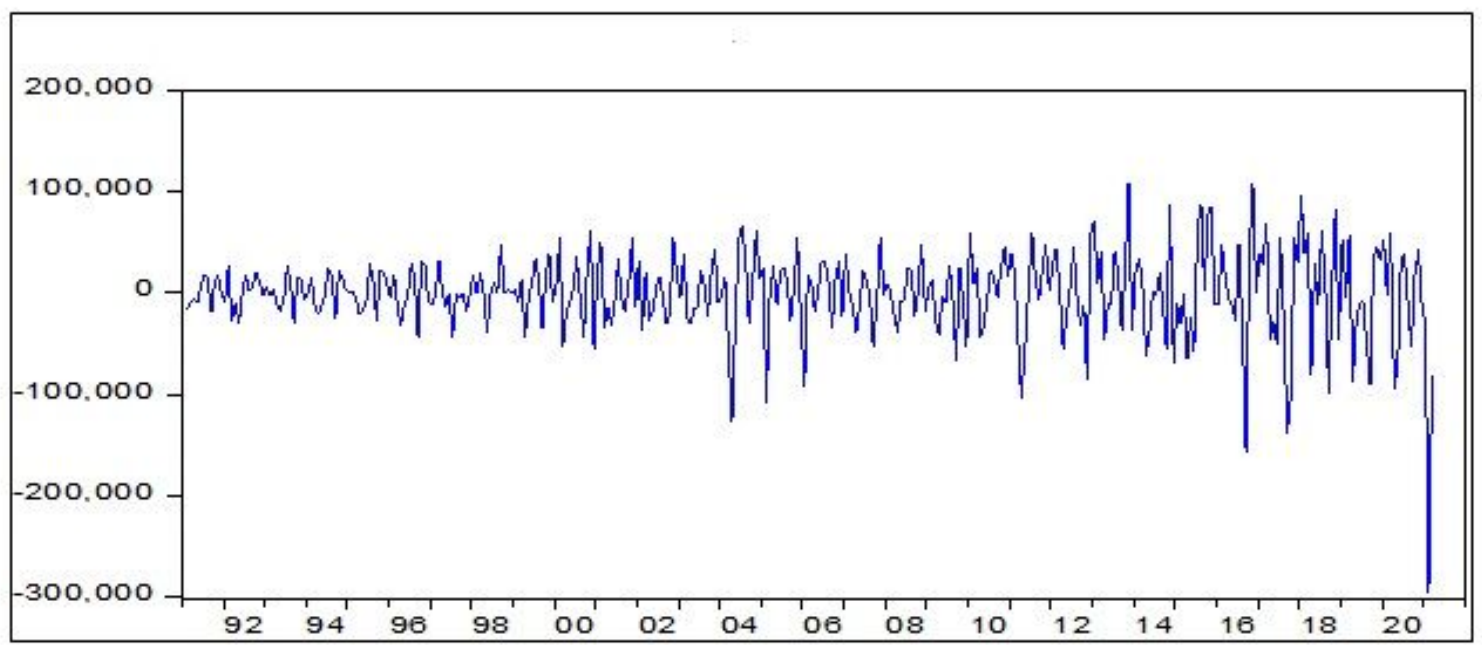

Figure 3. International Tourist Arrival Series with Difference. Source: Author Own by Using Eviews 10

\subsection{Autocorrelation and Partial Autocorrelation Function}

Similarly, another tool for identification of model can be used as ACF and PACF (Autocorrelation and Partial Autocorrelation function). Both plot Tourist Arrival series against lag length. The correlograms of Tourist Arrival and difference in Tourist Arrival series are plotted in Figure 4. Figure 4A up to 36 lags shows the ACF, and decline in autocorrelation gradually. The coefficient of correlation is declining slowly, and at each lag, it found is 
statistically significant (non-zero). Because they all are outside the $95 \%$ confidence bound, on the other hand, the PACF with second lag dropped dramatically while insignificant. Most of PACF are insignificant after 3rd lag till 13 lags. Since the tourist arrival series is non-stationary at the level. We have to make tourist arrival series before we move to B-J methodology. In Figure 5, the differencing the tourist arrival series, it shows ACF has good exponential decay and significant and non-zero at 2,12, 24, 26, and 36 lag, respectively. The PACF also seems significant and non-zero at 2,12,24, and 36 lag, respectively. That exhibits the ARIMA process because the ACF and PACF correlograms show a similar pattern. To identify an appropriate model, B-J emphasized on the Parsimonious model, that it can forecast than overparametrized models. Hence we observed to drive four tentative models as ARIMA $(2,1,2)$, ARIMA (2 1 12), ARIMA $(12,1,2)$, and ARIMA $(12,1,12)$ to forecast tourism demand in Thailand. It is not possible to drive the fitted model instead of doing trial and error.

\begin{tabular}{|c|c|c|c|c|c|c|}
\hline Autocorrelation & Partial Correlation & & $A C$ & PAC & Q-Stat & Prob \\
\hline 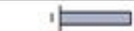 & בע" & & 0.943 & & 325.20 & 0.000 \\
\hline ביב & $\sqrt{1}$ & & 0.876 & -0.108 & 607.17 & 0.000 \\
\hline שב & ip & & 0.839 & 0.226 & 865.99 & 0.000 \\
\hline שב" & III & & 0.810 & 0.021 & 11082 & 0.000 \\
\hline 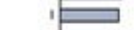 & if & & 0.781 & 0.034 & 1334.1 & 0.000 \\
\hline 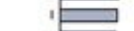 & if & & 0.755 & 0.034 & 1545.6 & 0.000 \\
\hline ב & 白 & & 0.740 & 0.104 & 1749.5 & 0.000 \\
\hline ב & 15 & & 0.739 & 0.129 & 1953.5 & 0.000 \\
\hline 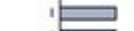 & 11 & & 0.734 & -0.000 & 2155.3 & 0.000 \\
\hline$\square$ & ' & 10 & 0.732 & 0.119 & 2356.7 & 0.000 \\
\hline 巴 & 13 & 11 & 0.738 & 0.085 & 2561.8 & 0.000 \\
\hline ב & in & 12 & 0.744 & 0.057 & 2770.8 & 0.000 \\
\hline 巴 & 도' & 13 & 0.715 & -0.270 & 2964.3 & 0.000 \\
\hline 业 & 'p & 14 & 0.687 & 0.114 & 3143.6 & 0.000 \\
\hline 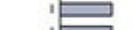 & 11 & 15 & 0.677 & 0.025 & 3317.9 & 0.000 \\
\hline 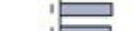 & wi & 16 & 0.672 & 0.053 & 3490.6 & 0.000 \\
\hline 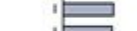 & '!' & 17 & 0.664 & 0.007 & 3659.5 & 0.000 \\
\hline ב & '. & 18 & 0.652 & 0.008 & 3823.0 & 0.000 \\
\hline ב" & II & 19 & 0.645 & 0.014 & 3983.1 & \\
\hline בש: & $y$ & 20 & 0.642 & & 41422 & \\
\hline Е & th & ${ }_{22}^{21}$ & 0.629 & & $\begin{array}{l}4295.5 \\
44446\end{array}$ & \\
\hline ב & ib & & 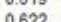 & 0.079 & $\begin{array}{l}44446.6 \\
45951\end{array}$ & $\begin{array}{l}0.000 \\
0.000\end{array}$ \\
\hline 业 & (1) & 24 & 0.624 & -010 & 47474 & 0,000 \\
\hline ש & di & 25 & 0.599 . & -0.144 & 48879 & 0.000 \\
\hline ב & "1 & 26 & 0.573 & 0.022 & 5016.9 & 0.000 \\
\hline$\rightleftarrows$ & iा & & & -0.016 & 5141.0 & \\
\hline$\rightleftarrows$ & '小 & 28 & & & 52628 & \\
\hline 巴 & 16 1 & & & -0.053 & 5378.5 & \\
\hline$\rightleftarrows$ & i1 & 30 & & & & \\
\hline 巴 & '1! & 31 & & 0.023 & & 0.0 \\
\hline$\Xi$ & 1. & 32 & & & 5686.5 & 0.000 \\
\hline 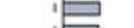 & 4! & 33 & 0.481 & -0.017 & 5779.5 & 0.000 \\
\hline e & 'is & 34 & 0.471 & 0.034 & 5869.0 & 0.000 \\
\hline 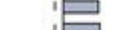 & in & 35 & 0.474 & 0.053 & 5959.7 & 0.000 \\
\hline 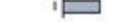 & & & & -0.027 & 16051.6 & 0.000 \\
\hline
\end{tabular}

A

\begin{tabular}{|c|c|c|c|c|c|}
\hline Autocorrelation & Partial Correlaston & $A C$ & PAC & Q-Stat & Prob \\
\hline 中 & 中 & 10.107 & & 4.1671 & \\
\hline 51 & Ci & $2-0.175$ & -0.188 & 15.340 & 0.000 \\
\hline 7, & ता & & -0.040 & 17.713 & 0.001 \\
\hline i & i & $\begin{array}{l}40.004 \\
\end{array}$ & -0.015 & 17.718 & 0.001 \\
\hline in & idi & $5=0.035$ & .0 .058 & 18. 176 & 0.003 \\
\hline I & $y_{1}$ & $6-0.111$ & -0.111 & 22730 & 0.001 \\
\hline 4 & I' & $7-0.113$ & .0 .112 & 27.432 & 0.000 \\
\hline in & 㘳 & 80.038 & 0.016 & 27.963 & 0.000 \\
\hline if & di & $9 \cdot 0.039$ & -0.109 & 28.529 & 0.001 \\
\hline d. & di & $10-0.079$ & -0.083 & 30.870 & 0.001 \\
\hline in & ' & 110.021 & -0.002 & 31.038 & 0.001 \\
\hline ص & ص & 120.363 & 0.327 & 80.708 & 0.000 \\
\hline di & 5 & $13 \cdot-0.025$ & .0 .150 & 80.944 & 0.000 \\
\hline E! & 1. & $14-0.171$ & -0.060 & 91.984 & 0.000 \\
\hline ? & 1. & $15-0.080$ & -0.053 & 94.423 & 0.000 \\
\hline in & it & $\begin{array}{ll}16 & 0.022 \\
17 & 0200\end{array}$ & -0.020 & 94.614 & 0.000 \\
\hline in & 背 & $\begin{array}{ll}17 & 0.019 \\
18 & -0.045\end{array}$ & -0.011 & $\begin{array}{l}94.747 \\
05570\end{array}$ & 0.000 \\
\hline 梦 & it & $\begin{array}{ll}18-0.046 \\
19\end{array}$ & $\begin{array}{l}-0.010 \\
0.051\end{array}$ & $\begin{array}{l}95.570 \\
95.670\end{array}$ & 0.000 \\
\hline 紧 & ib & $\begin{array}{l}19-0.016 \\
20 \\
0.113\end{array}$ & $\begin{array}{l}0.051 \\
0.47\end{array}$ & $\begin{array}{l}95.670 \\
10056\end{array}$ & $\begin{array}{l}0.000 \\
0.000\end{array}$ \\
\hline 党 & if & $21-0.024$ & -0.047 & 100.79 & 0.000 \\
\hline a & 1 & $22-0.107$ & $\begin{array}{l}-0.074 \\
-0.074\end{array}$ & 105.26 & 0.000 \\
\hline 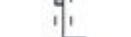 & in & 230.005 & 0.018 & 105.27 & 0.000 \\
\hline ש' & 尚 & $\begin{array}{ll}24 & 0.299\end{array}$ & 0.176 & 140.09 & 0.000 \\
\hline$\sqrt{1}$ & (1) & $25-0.016$ & -0.046 & 140.19 & 0.000 \\
\hline di & ii & $26-0.134$ & 0.021 & 147.20 & 0.000 \\
\hline 1 & is & $27-0.072$ & .0 .021 & 149.26 & 0.000 \\
\hline ib & is & 280.093 & 0.083 & 152.67 & 0.000 \\
\hline in & 4 & 290.035 & -0.030 & 153.16 & 0.000 \\
\hline di & is & $30-0.074$ & -0.018 & 155.36 & 0.000 \\
\hline it & in & $31-0.018$ & 0.047 & 155.49 & 0.000 \\
\hline p & I! & $32 \quad 0.067$ & -0.020 & 157.29 & 0.000 \\
\hline gi & d & $33-0.071$ & -0.051 & 159.32 & 0.000 \\
\hline di & is & $34-0.114$ & -0.041 & 164.59 & 0.000 \\
\hline 1' & L & $35-0.009$ & 0.013 & 164.62 & 0.000 \\
\hline 呐 & 卢 & $\begin{array}{ll}36 & 0.308\end{array}$ & 0.158 & 203.03 & 0.000 \\
\hline
\end{tabular}

B

Figure 4. Autocorrelation and Partial Autocorrelation function. Source: Author Own by Using Eviews 10

\subsection{Augmented Dickey-Fuller (ADF) and Phillips-Perron (PP) Unit Root Tests}

$A D F$ and PP tests are applied to check the stationary level of the series. The results ADF and PP test are reported in Table 1. The variable Tourist arrival exhibits non-stationary at the level as the calculated t-statistics for rejecting the null hypothesis is less than critical values at a $1 \%$ level of significance. While at the first difference, we are failed to accept the null hypothesis, that series has a unit root. These results also support the order of choosing order at the difference for our tourist arrival series.

Table 1. Unit Root Test

\begin{tabular}{cccccccccc}
\hline & \multicolumn{4}{c}{ ADF } & \multicolumn{4}{c}{ PP } \\
\cline { 2 - 10 } Variable & \multicolumn{2}{c}{ Level } & \multicolumn{2}{c}{ First difference } & \multicolumn{2}{c}{ Level } & \multicolumn{2}{c}{ First difference } \\
& C & C \& T & C & C \& T & C & C \& T & C & C \& T \\
\hline Tourist arrival & -1.860 & -2.525 & $-5.025^{*}$ & $-4.988^{*}$ & -2.776 & $-4.301^{*}$ & $-17.272^{*}$ & $-17.281^{*}$ \\
\hline
\end{tabular}

* shows significant at $1 \%$ level of significance. 


\subsection{Parameter estimation of ARIMA models}

Based on step 1, next step has statistically analyzed the following four tentative models as $\operatorname{ARIMA}(2,1,2), \operatorname{ARIMA}(2112), \operatorname{ARIMA}(12,1,2)$ and $\operatorname{ARIMA}(12,1,12)$ to predict the future trend of Tourist arrival in Thailand. The implementation of the techniques added new time series equations that are purely AR and MA process that the model predicts values and the residuals found under the $95 \%$ confidence intervals. The selection of appropriate models made possible by minimizes specific criteria, typically SBC, AIC, variance, and maximum likelihood, which suggested by other researchers (Preez and Witt, 2003). Alternatively, we have chosen the best ARIMA $(12,1,12)$ model consisting of AR (12), $d(1)$, and MA (12) process. The other 3 models also compared with the final $\operatorname{ARIMA}(12,1$, and 12) equation. As the "T-statistics found significant at $1 \%$ level of significance" meanwhile minimization criteria were found higher than that the ARIMA $(12,1,12)$ with the sigma squared and intercepted term. The results are reported in Table 2. As Table 2 indicate that, the equation ARIMA (12, 1, and 12) deliberately preferred over $\operatorname{ARIMA}(2,1$, and 2), $\operatorname{ARIMA}(2,1$, and 12), and ARIMA (12, 1, and 2). Because the t-statistics of coefficient $A R, M A$, and sigma squared found statistically significant and less volatile at a $1 \%$ level of significance, the adjusted R2 found higher than the rest of the 3 ARIMA equations. However, the AIC and SIC values found lower than the rest of the equation with F-statistics highly significant at a 1\% level of significance. In simple words, ARIMA (12, 1, 12) good fits than the other 3 more ARIMA equations. Thus to forecast tourist arrival in Thailand, for the next nine months ahead, we will only rely on $\operatorname{ARIMA}(12,1,12)$.

Table 2. ARIMA Equations

\begin{tabular}{ccccc}
\hline \multicolumn{2}{c}{ Method: ARMA (2 1 2) } & ARIMA (2, 1, 12) & ARIMA (12, 1, 2) & ARIMA (12, 1, 12) \\
\hline Variable & Coefficient & Coefficient & Coefficient & Coefficient \\
\hline C & 168.721 & -398.84 & -846.611 & -1721.80 \\
\hline S.E & {$[1684.33]$} & {$[2649.381]$} & {$[3279.985]$} & {$[12324.810]$} \\
T-statistic & $\mathbf{( S 0 . 1 0 0 )}$ & $\mathbf{( - 0 . 1 5 1 )}$ & $\mathbf{( - 0 . 2 5 8 )}$ & $\mathbf{( - 0 . 1 4 0 )}$ \\
\hline AR & 0.222 & -0.150 & 0.409 & 0.976 \\
\hline S.E & {$[0.193]$} & {$[0.054]$} & {$[0.044\}$} & {$[0.023]$} \\
\hline T-statistic & $\mathbf{( 1 . 1 5 0 )}$ & $\mathbf{( - 2 . 7 9 0 ) *}$ & $\mathbf{( 9 . 3 2 6 ) *}$ & $\mathbf{( 4 3 . 1 2 4 ) *}$ \\
\hline MA & -0.448 & 0.321 & -0.129 & -0.836 \\
S.E & {$[0.171]$} & {$[0.047]$} & {$[0.056]$} & {$[0.052]$} \\
\hline T-statistic & $\mathbf{( - 2 . 6 1 2 ) *}$ & $\mathbf{( 6 . 8 0 9 ) *}$ & $\mathbf{( - 2 . 3 1 1 ) * *}$ & $\mathbf{( - 1 5 . 9 8 0 )}$ \\
SIGMASQ & 1600000000 & 1450000000 & 1380000000 & 1220000000 \\
\hline S.E & {$[57948804]$} & {$[50727012]$} & {$[45441203]$} & {$[34248145]$} \\
\hline T-statistic & $\mathbf{( 2 7 . 5 5 7 ) *}$ & $\mathbf{( 2 8 . 4 9 5 ) *}$ & $\mathbf{( 3 0 . 3 9 3 ) *}$ & $\mathbf{3 5 . 7 4 5 ) *}$ \\
R ${ }^{2}$ & 0.043188 & 0.133926 & 0.172495 & 0.266483 \\
\hline Adj R & 0.03517 & 0.126668 & 0.165561 & 0.260337 \\
P-(F-Statistic) & 0.0012 & 0.0000 & 0.0000 & 0.0000 \\
\hline AIC & 24.05166 & 23.95538 & 23.91226 & 23.8142 \\
SIC & 24.09466 & 23.99838 & 23.95526 & 23.8572 \\
\hline
\end{tabular}

*and $1 \%$ level of significant.

\subsection{Diagnostic checking}

For the accuracy of our final ARIMA equation, we also followed the precautionary measure, to test correlogram Q-statistics, to evaluate the accuracy of ARIMA $(12,1$, and 12) equation. Figure 5A shows the correlogram of residuals for adjusted $\operatorname{ARIMA}(12,1,12)$ model, which found flat, and the results suggest that the forecasting of tourist arrival in Thailand must 
be done based on ARIMA (12 1 12). As we have seen, ACF and PACF are drawn against 36 lags, in which we found all lags are bound in $95 \%$ confidence interval and statistically insignificant. In simple words, we have left no information which should be captured.

Meanwhile, Figure 5B shows the Correlogram residual squared test, which indicates that there is no autocorrelation in this model. The flat correlogram of residual is perfectly ideal for ARMA or ARIMA analysis. That provides the critical standard error bounds, which indicates the correlation between residual, if so exist, ARIMA does not provide accurate forecasting.

\begin{tabular}{|c|c|c|c|c|c|c|}
\hline Autocorrelation & Partial Correlation & & $A C$ & PAC & Q-Stat & Prob \\
\hline 口 & 岿 & 1 & 0.175 & 0.175 & 11.117 & \\
\hline 19 & $\sqrt{1}$ & 2 & -0.052 & -0.085 & 12.102 & \\
\hline 11 & 11 & 3 & .0 .010 & 0.015 & 12.140 & 0.000 \\
\hline di & ci & 4 & -0.086 & -0.095 & 14.888 & 0.001 \\
\hline d, & 1) & 5 & -0.057 & -0.024 & 16.070 & 0.001 \\
\hline if & if & 6 & -0.044 & -0.044 & 16.803 & 0.002 \\
\hline di & di & 7 & .0 .106 & $=0.100$ & 21.005 & 0.001 \\
\hline 1 & 111 & 8 & -0.038 & -0.014 & 21.533 & 0.001 \\
\hline 11 & if 1 & 9 & -0.006 & -0.021 & 21.548 & 0.003 \\
\hline ifi & ifi & 10 & 0.035 & 0.030 & 22.006 & 0.005 \\
\hline 11 & 11 & 11 & 0.023 & -0.012 & 22.204 & 0.008 \\
\hline 16 & tit & 12 & 0.042 & 0.033 & 22870 & 0.011 \\
\hline if & 101 & 13 & -0.035 & -0.063 & 23.344 & 0.016 \\
\hline di & 19 & 14 & -0.061 & -0.049 & 24.766 & 0.016 \\
\hline if & 111 & 15 & -0.026 & -0.019 & 25.033 & 0.023 \\
\hline di & id 1 & 16 & .0 .053 & -0.052 & 26.088 & 0.025 \\
\hline 11 & 121 & 17 & 0.030 & 0.050 & 26.437 & 0.034 \\
\hline II & 11 & 18 & 0.037 & 0.006 & 26.972 & 0.042 \\
\hline if & 10 & 19 & 0.051 & 0.052 & 27.967 & 0.045 \\
\hline ip & 161 & 20 & 0.088 & 0.055 & 30.981 & 0.029 \\
\hline II & 1. & 21 & 0.022 & 0.007 & 31.174 & 0.039 \\
\hline 1 & 11 & 22 & -0.004 & -0.001 & 31.180 & 0.053 \\
\hline 1. & 11 & 23 & -0.006 & -0.005 & 31.192 & 0.071 \\
\hline if & 11 & 24 & -0.021 & 0.004 & 31.368 & 0.089 \\
\hline 11 & 11 & 25 & $=0.015$ & 0.006 & 31.451 & 0.112 \\
\hline 11 & t. $t$ & 26 & -0.016 & 0.007 & 31.549 & 0.139 \\
\hline if & 11 & 27 & -0.027 & -0.015 & 31.837 & 0.163 \\
\hline 19 & ip & 28 & 0.056 & 0.072 & 33.092 & 0.159 \\
\hline if & 11 & 29 & 0.054 & 0.020 & 34.234 & 0.159 \\
\hline 11 & 14t & 30 & $=0.018$ & -0.034 & 34.369 & 0.189 \\
\hline ib & 10 & 31 & 0.049 & 0.065 & 35.334 & 0.194 \\
\hline if & 11 & 32 & 0.026 & 0.007 & 35.613 & 0.221 \\
\hline di & if 1 & 33 & -0.054 & -0.029 & 36.774 & 0.219 \\
\hline 11 & 11 & 34 & $=0.020$ & 0.005 & 36.943 & 0.251 \\
\hline 11 & 111 & 35 & -0.041 & -0.023 & 37.614 & 0.266 \\
\hline 111 & ip & 36 & 0.039 & 0.076 & 38.236 & 0.283 \\
\hline
\end{tabular}

A

\begin{tabular}{|c|c|c|c|c|c|c|}
\hline Autocorrelation & Partial Correlation & & $A C$ & PAC & Q-Stat & Prob \\
\hline p & 中 & 1 & 0.152 & 0.152 & 8.4071 & 0.004 \\
\hline iा & 1 & 2 & 0.015 & .0 .008 & 8.4914 & 0.014 \\
\hline 11 & 11 & 3 & 0.000 & -0.001 & 8.4914 & 0.037 \\
\hline i. & i & 4 & -0.000 & 0.000 & 8.4914 & 0.075 \\
\hline 11 & 11 & 5 & -0.016 & -0.017 & 8.5887 & 0.127 \\
\hline 11 & 11 & 6 & -0.005 & 0.000 & 8.5966 & 0.198 \\
\hline 1. & 1. & 7 & -0.002 & -0.001 & 85978 & 0.283 \\
\hline if & ifi & 8 & 0.015 & 0.016 & 8.6812 & 0.370 \\
\hline ifi. & ifi & 9 & 0.026 & 0.022 & 8.9327 & 0.444 \\
\hline ifi. & ifi & 10 & 0.040 & 0.033 & 9.5333 & 0.482 \\
\hline if & ifi & 11 & 0.040 & 0.030 & 10.148 & 0.517 \\
\hline If1 & If & 12 & 0.030 & 0.019 & 10.483 & 0.574 \\
\hline ifi & if & 13 & 0.033 & 0.027 & 10.902 & 0.619 \\
\hline in & i & 14 & 0.010 & 0.002 & 10.943 & 0.691 \\
\hline 11 & 11 & 15 & -0.002 & -0.003 & 10.944 & 0.757 \\
\hline 1.1 & if & 16 & 0.006 & 0.009 & 10.960 & 0.812 \\
\hline 11 & 11 & 17 & 0.001 & -0.001 & 10.960 & 0.859 \\
\hline in & iाi & 18 & 0.022 & 0.023 & 11.152 & 0.888 \\
\hline ifi & if & 19 & 0.023 & 0.015 & 11.357 & 0.911 \\
\hline 1,1 & in & 20 & -0.002 & -0.011 & 11.359 & 0.936 \\
\hline if & if & 21 & 0.013 & 0.012 & 11.424 & 0.954 \\
\hline if & I1 & 22 & 0.017 & 0.010 & 11.535 & 0.966 \\
\hline in & 1,1 & 23 & 0.033 & 0.027 & 11.966 & 0.971 \\
\hline If & 1.1 & 24 & 0.009 & -0.002 & 11.995 & 0.980 \\
\hline 1. & i. & 25 & 0.001 & -0.002 & 11.996 & 0.987 \\
\hline If & if & 26 & 0.018 & 0.017 & 12.117 & 0.990 \\
\hline 1.1 & i. & 27 & 0.008 & 0.001 & 12.143 & 0.994 \\
\hline$\pi$ & 11 & 28 & -0.008 & -0.011 & 12.170 & 0.996 \\
\hline in & if & 29 & 0.012 & 0.012 & 12224 & 0.997 \\
\hline if & if & 30 & -0.012 & -0.018 & 12279 & 0.998 \\
\hline ifi & ifi & 31 & 0.010 & 0.012 & 12320 & 0.999 \\
\hline 1. & if & 32 & -0.004 & -0.011 & 12.325 & 0.999 \\
\hline If & 11 & 33 & 0.023 & 0.022 & 12.533 & 1.000 \\
\hline ifi & ifi & 34 & 0.031 & 0.022 & 12.916 & 1.000 \\
\hline if & if & 35 & 0.027 & 0.016 & 13.214 & 1.000 \\
\hline $1 / 1$ & $1 / 1$ & 36 & 0.007 & -0.002 & 13.233 & 1.000 \\
\hline
\end{tabular}

B

Figure 5. Correlogram residual squared test

\subsection{Forecasting tourist arrival}

The last and final step is to forecast international tourist arrival in Thailand. We have critically analyzed our model base on four stages. The ARIMA $(12,1$, and 12) is correctly used to forecast international tourist arrival from April 2020 to December 2020. The more extended series we obtained from January 1991 to March 2020 enables us to predict well based on enough past values of tourist arrival. However, we also use the order ARIMA equation with different lag orders of AR and MA processes to forecast future trends with a reasonable difference.

Moreover, our primary focus is only ARIMA AR (12) d (1) and MA (12) process. The forecasted trend represented in Figure 6 . It can be seen the forecasted international tourist arrival easily will be effected from April 2020 till December 2020. The decline gradually in the negative zone, which means the foreign tourist, will not visit Thailand in the future.

Due to this fact, the world economies are lockdown due to deadly pandemic. That will not only affect the tourism industry of Thailand but also the economy as a whole. Our forecast is provided prediction, but econometric models rely on figures that do not lie. Moreover, the results are robust as other models also indicate the gradual decline in international tourists' arrival in Thailand. 


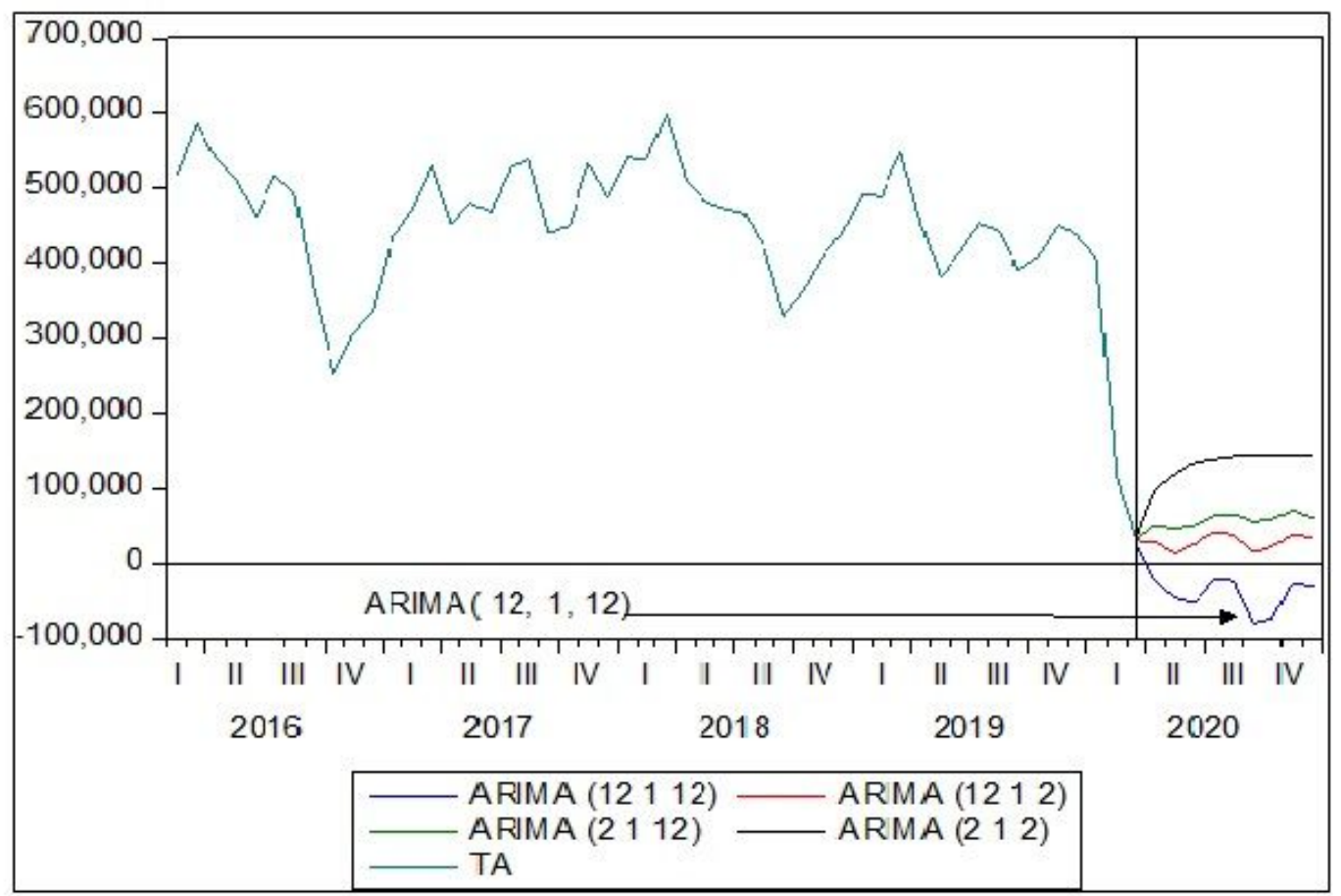

Figure 6. Forecasting for International Tourist Arrival for next 9 months

\section{CONCLUSION AND POLICY RECOMMENDATIONS}

Thailand Ranked at the ninth place from the East Asian region for international tourists. Millions of international tourist arrivals were recorded in Thailand for many decades. The outbreak of COVIV-19 has been put a significant impact on the economic atmosphere around the world; mainly it severely affected the Thailand tourism industry. It is better to know how much its impact could remain, and more people would be lost their jobs remain under distracted due to such effect. In order to know, we conducted an empirical study to forecast one of the primary contributing sectors of Thailand's economy. The study used univariate forecasting since we had enough monthly observations of international tourist arrival from Jan 1991 to March 2020. The study shows the significant declined in international visitors in March as a Covid-19 outbreak all around the world in February. We also observed the seasonal average of international visitors, which showed from February to March, as Thailand received highest international tourists in the same previous month. However, unfortunately, the tourism industries of Thailand experience a significant decline in international arrivals as the worlds are in a lockdown situation. We also performed the time series ARIMA (12, 1, and 12) forecasting based on the B-J four-step methodology to observe the next nine months of the year 2020 for the tourism industry. We estimated several ARIMA models in order to pick an appropriate one. The evidence shows that the demand for tourism arrival will be possible in Thailand. Our forecast provides prediction, but econometric models rely on the figure that does not lie. Moreover, the results are robust as other models also indicate the gradually declines in the international tourist arrival of Thailand. Furthermore, Thailand should also focus on its logistic performance so that; Thailand can attract more tourists around as limcharoen et al. (2017) mention in their work logic performance index not indicating satisfactory outcomes. Furthermore, Thailand should also focus on renewable energy in overall logistics operations, as it ultimately improves environment performance by reducing emission whereas environmental performance is negatively correlated with public health expenditure as explained by (Khan et al., 2020). As after pandemic Thailand need more inbound tourist to enhance its economic cycle; therefore, Thailand must put more efforts to increase its renewable energy sector. Similarly, the government of Thailand should also promote a green ideology, which will ultimately reduce air pollution and on the other hand 
green concept will improve countries, social, economic and environmental performance as recommended by Khan et al. (2019). Along with renewable energy, Thailand should also focus on its railway infrastructure and road transportation as it enhances the overall tourism sector, as mentioned by Khan et al. (2017)].

\section{ACKNOWLEDGEMENT}

This work partially supported by the Beijing Key Laboratory of Megaregions Sustainable Development Modelling, Capital University of Economics and Business (No. MCR2019QN09).

\section{REFERENCES:}

Blackwell, R. (2007), "Motivations for religious tourism, pilgrimage, festivals and events", in Raj, R. and Griffin, K. (Eds.), Religious Tourism and Pilgrimage Festivals Management: An International Perspective, $C A B I$, Wallingford, pp. 35-47.

Box, G.E.P. and Jenkins, G.M. (1976), Time Series Analysis: Forecasting and Control, 2nd ed., Holden-Day, San Francisco.

Chancharat, S. (2011), "Thai tourism and economic development: the current state of research", Kasetsart Journal of Social Sciences, Vol. 32, No. 2, pp. 340-51.

Chen, C.F. and Chiou-Wei, S.Z. (2009), "Tourism expansion, tourism uncertainty and economic growth: new evidence from Taiwan and Korea", Tourism Management, Vol. 30, No. 6, pp. 812-8.

Chou, M.C. (2013), "Does tourism development promote economic growth in transition countries? A panel data analysis", Economic Modelling, Vol. 33, pp. 226-32.

Cortes-Jimenez, I. and Pulina, M. (2010), "Inbound tourism and long-run economic growth", Current Issues in Tourism, Vol. 13, No. 1, pp. 61-74.

Dash, A.K., Tiwari, A.K. and Singh, P.K. (2018), "Tourism and economic growth in India: an empirical analysis", Indian Journal of Economics, Vol. 392, pp. 29-49.

Department of Religious Affairs (2015), “DRA information site", available at: http://www.dra.gov.mm/ (accessed 19 April 2020).

Farzanegan, M.R., Gholipour, H.F., Feizi, M. et al. (2020), "International tourism and outbreak of coronavirus (COVID-19): a cross-country analysis", Journal of Travel Research. In press.

Khan, S.A.R. and Qianli, D. (2017), "Travel and tourism competitiveness index: The impact of air transportation, railways transportation, travel and transport services on international inbound and outbound tourism", Journal of Air Transport Management, Vol. 58, pp. 125-34.

Khan, S.A.R., Sharif, A., Golpîra, H. et al. (2019), "A green ideology in Asian emerging economies: from environmental policy and sustainable development", Sustainable Development, Vol. 27, No. 6, pp. 1063-75.

Limcharoen, A., Jangkrajarng, V., Wisittipanich, W. et al. (2017), "Thailand logistics trend: logistics performance index", International Journal of Applied Engineering Research, Vol. 12, No. 15, pp. 4882-5.

Luton, L.S. (2015), Qualitative Research Approaches for Public Administration, Routledge, London.

Neef, A. and Grayman, J.H. (2018), "The tourism-disaster-conflict nexus", Community, Environment and Disaster Risk Management, Vol. 19, pp. 1-31.

Ongan, S. and Demiroz, D.M. (2005), "The contribution of tourism to the long-run Turkish economic growth", Ekonomicky Casopis, Vol. 53, No. 9, pp. 880-94.

Pourtaheri, M., Rahmani, K. and Ahmadi, H. (2012), "Impacts of religious and pilgrimage tourism in rural areas: the case of Iran", Journal of Geography and Geology, Vol. 4, No. 3, pp. 1-8.

Preez, J. and Witt, S.F. (2003), "Univariate versus multivariate time series forecasting: an application to international tourism demand", International Journal of Forecasting, Vol. 19, No. 3, pp. 435-51.

Prideaux, B., Laws, E. and Faulkner, B. (2003), "Events in Indonesia: exploring the limits to formal tourism trends forecasting methods in complex crisis situation", Tourism Management, Vol. 24, No. 4, pp. 475-87. 
Rehman Khan, S.A., Zhang, Y., Kumar, A. et al. (2020), "Measuring the impact of renewable energy, public health expenditure, logistics, and environmental perfomance on sustainable economic growth", Sustainable Development, Vol. 28, No. 4, pp. 833-43.

Religious Information Center (2020), "Ministry of Culture”, available at: www.m-culture.go.th (accessed 19 April 2020).

Selimi, N., Sadiku, M. and Sadiku, L. (2017), "The impact of tourism on economic growth in the western balkan countries: an empirical analysis", International Journal of Business and Economic Sciences Applied Research, Vol. 10, No. 2, pp. 19-25.

Um, S. and Crompton, J.L. (1990), "Attitude determinants in tourism destination choice", Annals of Tourism Research, Vol. 17, No. 3, pp. 432-48.

Wattanakuljarus, A. and Coxhead, I. (2008), "Is tourism-based development good for the poor? A general equilibrium analysis for Thailand", Journal of Policy Modeling, Vol. 30, No. 6, pp. 929-55.

World Tourism Organization (2020), available at: https://www.unwto.org/ (accessed 19 April 2020).

Author contributions: All the authors contributed equally to this paper. 